\title{
Special Section on Product Development: Introduction
}

\author{
F Anthony Bushman, Drexel University \\ C Merle Crawford, University of Michigan
}

\section{Development and Marketing of New Products: A Research Progress Report}

Early in 1980 a general call for research papers on the subject of product development was widely distributed in the appropnate academic disciplines and in sclected business firms Over the following year we received a flow of manuscripts from which were selected the ones appeanng in this issue Customary blind reviewing procedures were used

These papers represent research on important topics related to new product development and marketıng Giese and Weisenberger address the career paths of product managers-how they enter the marketing profession and advance through the organization They develop profiles of product managers' educational background, training, and personal skılls

Moore's article classifies what is typically covered in concept tests and notes dissatisfactions with concept testing He suggests different research approaches for concept generation, screenıng, and concept evaluation

Rabino and Moskowitz on a more detalled level address the issue of optımızing the product development process by using systematıc variations of product ingredients through fractional factonal designs and nonlinear quadratic equations

What these papers do not reveal, however, is a potentrally dangerous and costly misdirection of new product research While new product development and management has been practiced as an active business discipline since late in the eighteenth century, it has been taught in universities only in the very recent past Engineenng courses have existed for many years Specialızed centers in such subspecialties as industrial design exist of vanous schools, but the management of the task first evolved in the 1950s, and even today we find courses on new product marketıng management at fewer than one hundred schools

Address correspondence to $F$ Anthony Bushman, College of Business and Administratton, Drexel Untversity, Philadelphia, PA 19104 
Coinciding with the slow growth of the academic discipline has been a very rapid nse in the national need for new products Innovation is sought across all of the well-publicized social frontiers (e $g$, environmental control and consumer purchasing) but is also of increasing prionty in our efforts to increase America's productivity and its worldwide economic competitiveness Never in this nation's history has there been such a demand for enhanced new product flow, and yet the demand meets a paucity of managenal capability Our research has been too little, too late, too irrelevant - and marked more by its absence than it presence

To stimulate a far more productive flow of research on new product development, we cite the following needs

1 The social-legal front If business firms are to find new products of special social value, they need far more information on consumers' (and industries') value systems-what they see as meaningful economic/social tradeoffs, their state of satısfaction with the social values incorporated in their current products

Business cannot effectively forecast future legal turns without more knowledge of the public mood Recent court decisions on market-share liability in antitrust matters, product supenonty as the defense against monoply charges, and various parts of the proposed Model Uniform Product Liability Act all suggest our forecasting weaknesses As of now it is probably safe to conclude that most firms do not fully understand these recent legal actions and their future impact on the firm

2 Buyer behavior Although we have seen an explosion in consumer buyer behavior studies in the 1970 s, there is today no summary of the findings as they relate to new products, and no new products decision model more advanced than some of the diffusion of innovation concepts now over 20 years old

3 Concept generation An inconceivable dereliction of professional research responsibility appears to exist across the entire field of concept generation We have in recent years seen a few attempts to create systems of idea creation but they are few and virtually without published research validation Even the specific creativity-stımulatıng techniques so well known to us all (e $\mathrm{g}$, brainstorming, checklısts, and attribute analyses) are amazingly underresearched We simply do not know what techniques will work, under what conditions, and with what relative effectiveness But this does not appear to retard the generation of still more such techniques, the total list of which is now well past one hundred' 
4 Organization for product development Over the past 20 years several new organizational approaches have been proposed (and described at length) for use in product development-the new products product manager, the new products director, the product planning director, the venture groups, the product development project matnix, and several other variants on the team or task force approach In spite of many descriptions of these organizational devices, the general manager today simply has no researched and proven approach for deciding which of these many devices should be used

5 Market testing Some leading new products manufacturers and marketing research firms have been prolific since the mid-1960s in creating new alternatives to the ternbly expensive (and often unreliable) test market as a device for putting the new product and its marketıng plan through a final examınation The devices vary from simple interviewing prodedures through cable TV tests and up to several extremely complex mathematical models Many of these approaches are apparently selling well today, if we are to believe ads and conference speeches Yet controversy abounds For every leadıng firm that swears by one of them, there is another leadıng firm that swears at it Whom are we to believe? Why is there no sound research to evaluate them in such a way as to permit reasoned usage decisions? If the propnetary restriction of industry is applicable here, it is not in the best interest of the new product development discipline

6 Contingency planning It was approximately 25 years ago that statisticians and operations research people successfully established the concept of risk analysis as a component of the decision process for deciding between alternatives Not long afterward, these technıques led to the type of decision tree applications that utılized "expected value of outcomes" to yield a solid technology for contingency planning Yet the evidence we have today suggests very little contingency planning on new products, either during the development process or during market introduction Why not? Is the technology not applicable to new products? Has it been researched? Have alternative systems been developed?

7 New product strategy Recent research has begun to identify the actual structure or format of new product strategy statements, but at no time has any serious research addressed the question of how new product strategies should be developed The success or fallure of various firms has not been ngorously assessed, nor have theoretical constructs been developed on which empincal studies could be based 
8 New product theory Beyond the more managerial aspects emdodied in much of the above, there has been no effort to develop new product theory The field has no unifying body of principles for developing and marketing new products

These research needs are the opinions of the two of us as special cditors But there are divergent vicws, as disclosed in the conversations surrounding the gathenng, evaluatıng, and revising of the research reports printed in this special issue These views are so conflicting that there is even gross inadequacy in research on the question of research need

Therefore we have persuaded the Product Development and Management Association to cooperate in a study designed to determine

1 What facets of the entıre new product development task most need research today?

2 Which facets of the task are being researched today or are currently scheduled for research in the near future?

3 What are the gaps as indicated in the companison of those two lists, and what actions can be suggested to meet the unaddressed needs?

The findings from this study should be avallable in the near future 